\title{
Protocol routing
}

Muji setia

175100027

Fakultas Komputer

mujisetia.student@umitra.ac.id

\begin{abstract}
Abstrak
Protocol adalah jaringan telekomunikasi yang memungkinkan antar komputer untuk saling berkomunikasi dengan bertukar data. Pada jaringan tersebut banyak sekali rute yang digunakan untuk menyambungkan satu jaringan dengan yang lainnya agar bisa tersambung atau berkomunikasi. Salah satu rute untuk meyambungkan jaringan satu dengan yang lainnya adalah Routing

Routing adalah suatu protokol yang digunakan untuk mendapatkan rute dari satu jaringan ke jaringan yang lain. Dimana rute yaang digunakannya rute yang paling dekat. Selain itu routing juga memiliki dua jenis yaitu statis dan dynamic. Kedua jenis itu juga memiliki kelebihan dan kekurangan masing masing.
\end{abstract}

Kunci : PROTOCOL ROUTING 
Fakultas Komputer

TUGAS 1 - 88675543

PENDAHULUAN

Jaringan komputer (jaringan) adalah

jaringan telekomunikasi yang

memungkinkan antar komputer untuk

saling berkomunikasi dengan bertukar

data. Pada jaringan tersebut banyak sekali

rute yang digunakan untuk

menyambungkan satu jaringan dengan

yang lainnya agar bisa tersambung atau

berkomunikasi. Salah satu rute untuk

meyambungkan jaringan satu dengan yang

lainnya adalah Routing

Routing adalah suatu protokol yang

digunakan untuk mendapatkan rute dari

satu jaringan ke jaringan yang lain. Dimana rute yaang digunakannya rute yang paling

dekat. Selain itu routing juga memiliki dua jenis yaitu statis dan dynamic. Kedua jenis itu juga memiliki kelebihan dan kekurangan masing masing.

\section{PEMBAHASAN}

Pengertian Routing

Routing adalah suatu protokol yang

digunakan untuk mendapatkan rute dari

satu jaringan ke jaringan yang lain. Rute ini, disebut dengan route dan informasi

route secara dinamis dapat diberikan ke

router yang lain ataupun dapat diberikan

secara statis ke router lain.

Routing adalah proses dimana suatu router mem-forward paket ke jaringan yang dituju.

Suatu router membuat keputusan

berdasarkan IP address yang dituju oleh

paket. Semua router menggunakan IP address tujuan untuk mengirim paket. Agar keputusan routing tersebut benar, router harus belajar bagaimana untuk mencapai tujuan. Ketika router menggunakan routing dinamis, informasi ini dipelajari dari router yang lain. Ketika menggunakan routing statis, seorang network administrator mengkonfigurasi informasi tentang jaringan yang ingin dituju secara manual.

Jika routing yang digunakan adalah statis, maka konfigurasinya harus dilakukan
Muji Setia

secara manual, administrator jaringan harus memasukkan atau menghapus rute statis jika terjadi perubahan topologi. Pada jaringan skala besar, jika tetap menggunakan routing statis, maka akan sangat membuang waktu administrator jaringan untuk melakukan update table routing. Karena itu routing statis hanya mungkin dilakukan untuk jaringan skala kecil. Sedangkan routing dinamis bisa diterapkan di jaringan skala besar dan membutuhkan kemampuan lebih dari administrator

\section{ID SECURITY}

\section{DISKUSI}


TUGAS 1 - 88675543

Teman saya bernama MARINA berpendapat tentang mengenai protocol routing

adalah layanan yang secara otomatis memberikan nomor IP kepada komputer yang memintanya. Komputer yang memberikan nomor IP disebut sebagaiDHCP server, sedangkan komputer yang meminta nomor IP disebut sebagai DHCP Client.
Buku Jaringan Komputer I Sritrusta

Sukaridhoto, ST. Ph.D. Politeknik

Elektronika Negeri Surabaya (PENS) - 2014

\section{KESIMULAN}

Routing adalah suatu protokol yang digunakan untuk mendapatkan rute dari satu jaringan ke jaringan yang lain. Rute ini, disebut dengan route dan informasi route secara dinamis dapat diberikan ke router yang lain ataupun dapat diberikan secara statis ke router lain.

Routing static adalah entri suatu route yang dilakukan oleh seorang administrator untuk mengatur jalur dari sebuah paket data.

Routing dinamis adalah ketika routing protokol digunakan untuk menemukan network dan melakukan update routing table pada router. Routing dinamis adalah ketika routing protokol digunakan untuk menemukan network dan melakukan update routing table pada router.

Contoh routing protokol: Routing Information Protocol (RIP), Interior Gateway Routing Protocol (IGRP), Enhanced Interior Gateway Routing Protocol (EIGRP), Open Shortest Path First (OSPF)

DAFTAR PUSTAKA

Buku Ajar Modul 1Mikrotik Operating System Jaringan Komputer 
$\begin{array}{ll}\stackrel{\text { Fakultas Komputer }}{\Perp} & \text { TUGAS } \mathbf{1}-\mathbf{8 8 6 7 5 5 4 3}\end{array}$

Muji Setia 